\title{
Insights for policy-based conservation strategies for the Rio de la Plata Grasslands through the IPBES framework
}

\author{
Antonella Gorosábel ${ }^{1 *}$, Lucrecia Estigarribia ${ }^{2+*}{ }^{+}$, Luis Filipe Lopes $^{3 \dagger}$, Ana Maria Martinez $z^{4}$, Juan Andrés Martínez- \\ Lanfranco $^{5}$, Ademola Andrew Adenle ${ }^{6,7}{ }^{1}$, Carla Rivera-Rebella ${ }^{8,9}$ \& Muhammed A. Oyinlola ${ }^{10}$ \\ ${ }^{1}$ CONICET, Grupo de Recursos Naturales y Gestión Ambiental, Instituto Nacional de Tecnología Agropecuaria, \\ Estación Experimental Agropecuaria Balcarce, Argentina. \\ ${ }_{2}^{2}$ Instituto Multidisciplinario de Biología Vegetal, Universidad Nacional de Córdoba, CONICET, Facultad de Ciencias \\ Exactas, Físicas y Naturales, CC 495, 5000 Córdoba, Argentina. \\ ${ }^{3}$ Universidade de Lisboa, Instituto Superior de Agronomia, Centro de Ecologia Aplicada "Professor Baeta Neves", \\ Lisboa, Portugal. \\ ${ }^{4}$ Faculty of Environmental Studies, York University, Toronto, Canada. \\ ${ }^{5}$ University of Alberta, Department of Biological Sciences, Edmonton, Canada. \\ ${ }^{6}$ University of Bern, Institute of Geography, Hallerstrasse 12, CH-3012 Bern, Switzerland. \\ ${ }^{7}$ Federal University of Technology, Department of Geography, Minna, Niger, Nigeria. \\ ${ }^{8}$ Center of Applied Ecology and Sustainability, Santiago, Chile. \\ ${ }^{9}$ Pontificia Universidad Católica de Chile, Departamento de Ecología, Facultad de Ciencias Biológicas, Santiago, \\ Chile. \\ ${ }^{10}$ University of British Columbia, Institute for the Oceans and Fisheries, Changing Ocean Research Unit, 2202 Main \\ Mall, Vancouver, B.C. V6T 1Z4, Canada. \\ *Corresponding author: Lucrecia Estigarribia, email: lucreciaestigarribia@gmail.com \\ ${ }^{\top}$ These authors contributed equally to this work.
}

GOROSÁBEL, A., ESTIGARRIBIA, L., LOPES, L.F., MARTINEZ, A.M, MARTÍNEZ-LANFRANCO, J.A, ADENLE, A.A., RIVERA-REBELLA, C., OYINLOLA, M.A. Insights for policy-based conservation strategies for the Rio de la Plata Grasslands through the IPBES framework. Biota Neotropica 20(suppl. 1): e20190902, 2020. https://doi.org/10.1590/16760611-BN-2019-0902

\begin{abstract}
The Río de la Plata Grasslands (RPG) are one of the most modified biomes in the world. Changes in land use and cover affect the RPG's rich biodiversity. In particular, the expansion of crops, overgrazing, afforestation, and the introduction of exotic species pose a major threat to the conservation of biodiversity and ecosystem services (BES). In this study, we applied the Intergovernmental Platform on Biodiversity and Ecosystem Services (IPBES) conceptual framework as a new lens to approach biodiversity conservation enactments in the RPG. First, we systematically reviewed published scientific literature to identify direct and indirect drivers that affect the RPG's BES. Further, we conducted an extensive analysis of management policies affecting the BES directly in the region, at a national and international level. We conclude by offering recommendations for policy and praxis under the umbrella of the IPBES framework.
\end{abstract}

Keywords: Land Use Change; Biodiversity; Ecosystem Services; Drivers, Nature's Contributions to People.

\section{Insights para estratégias de conservação baseadas em políticas para as pradarias do Rio da Prata através da estrutura do IPBES}

Resumo: As pradarias do Rio da Prata são um dos biomas mais modificados no mundo. Alterações nos usos do solo afetam a rica biodiversidade deste ecossistema. A expansão da agricultura, sobrepastoreio, arborização e a introdução de espécies exóticas, principalmente, representam uma grande ameaça para a conservação da biodiversidade e dos serviços ecossistêmicos (BES). Neste estudo, aplicamos a estrutura conceptual da Plataforma Intergovernamental sobre Biodiversidade e Serviços Ecossistêmicos (IPBES) como uma nova forma de abordar as políticas de conservação da biodiversidade neste bioma. Primeiro, revisamos sistematicamente artigos científicos publicados de forma a identificar fatores diretos e indiretos que afetam os BES nas pradarias do Rio da Prata. Adicionalmente, realizamos uma extensa análise das políticas de gestão que afetam diretamente os BES na região, quer a nível nacional, quer internacional. Concluímos com propostas e recomendações de políticas e práticas sob a égide do quadro do IPBES.

Palavras-chave: Alterações de Uso do Solo; Biodiversidade; Serviços Ecossistêmicos; Contribuições da Natureza para as Pessoas. 


\section{Introduction}

Obtaining natural resources for fulfilling human needs has been made at the expense of environmental degradation (Foley et al. 2005, MEA 2005, Zhang et al. 2019a). Based on the current trends in land use and land cover (LULC) changes worldwide, humans can obtain goods and services to improve their quality of life only by diminishing the capacity of global ecosystems to sustain the provision of such benefits (Foley et al. 2005, MEA 2005). Hence, contemporary societies face the challenge of developing regional land-use strategies that recognize short and long-term needs while reducing the negative environmental impacts and maintaining social and economic benefits (Foley et al. 2005, MEA 2005).

The Intergovernmental Science-Policy Platform on Biodiversity and Ecosystem Services (IPBES) is an international body that works to strengthen the science-policy interface for biodiversity and ecosystem services. IPBES aims to assess the state of biodiversity and ecosystem services (BES) incorporating different disciplines and types of knowledge (Díaz et al. 2015). Nature's contribution to people (NCP) is a concept promoted by IPBES that refers to all the positive and negative contributions of nature to the quality of life of people, which can be recognized and valued in a range of existing worldviews. This approach underlines the central and pervasive role that culture plays in defining all links between people and nature (Díaz et al. 2018). According to Pascual et al. (2017), a multiple value perspective should be encouraged in decision making, focusing on three types of values: intrinsic, relational, and instrumental. In order to achieve sustainable development, it is important to consider long-term human well-being, the drivers, and the consequences of land-use changes (Crossman et al. 2013, Nagendra et al. 2013, Ellis et al. 2019). Therefore, the link between drivers, valuations, and NCPs might serve as holistic guidance for policy formulation.

Grasslands are one of the most modified biomes of the world (Hannah et al. 1995, Paruelo et al. 2007, Baldi \& Paruelo 2008), which cover over 50 million $\mathrm{km}^{2}$, accounting for $37 \%$ of the earth's terrestrial surface (O'Mara 2012). Native grasslands have been replaced or degraded by intensively managed agricultural lands (Hannah et al. 1995, Vega et al. 2009, O'Mara 2012, Gang et al. 2014), representing $70 \%$ of the agricultural areas worldwide (Schlesinger \& Andrews 2000, Ramesh et al. 2019). Thus, grasslands play a unique role in food security by providing agricultural products (O’Mara 2012).

In the Neotropics, the Río de la Plata Grasslands (RPG) are the most extensive grassland ecosystem, covering an extent of 750,000 $\mathrm{km}^{2}$ (Soriano et al. 1991, Carbutt et al. 2011). The RPGs are shared by eastern Argentina, southern Brazil, and Uruguay, encompassing two main sub-regions, Pampas and Campos (Soriano et al. 1991) (Figure 1). The mean annual temperature of the region is 10 to $20^{\circ} \mathrm{C}$, and the mean annual rainfall is between 400 and 1,600 $\mathrm{mm}$ (Soriano et al. 1991).

After the European colonization, the native grasslands of the RPG have become one of the most essential regions of grain and beef production in the world (Bilenca \& Miñarro 2004, Paruelo et al. 2005, Baldi et al. 2006). Until the $20^{\text {th }}$ century, cattle ranching was the most common and important land use, but then, cropping became the most important one (Vervoorst 1967, Soriano et al. 1991, Viglizzo et al. 2001, Baldi et al. 2006). For example, between 2000 and 2010, the cultivation of genetically modified soybean generated an intensification and expansion of monocultures of this crop in the region (Aizen et al. 2009, Redo et al. 2012, Modernel et al. 2016). Although there was a predominance of soybean, other crops also increased, such as sunflower, maize, rice, wheat, pine, and eucalyptus (Baldi \& Paruelo 2008, Cubbage et al. 2012). In the last decade, the cropping systems became less diverse raising concerns about the sustainability and environmental risks associated with crop production in a region which is relevant for the world grain and oil market (FAO 2014). As such, the RPG have represented one of the most rapidly expanding agricultural frontiers not only in Latin America but in the world (Baeza \& Paruelo 2020). Currently, most of the area is represented by sown pastures, annual crops, overgrazed areas, and tree plantations, and only a small portion of semi-natural native grasslands remain (Modernel et al. 2016, Paruelo et al. 2005).

All aforementioned LULC changes have affected the ecosystem functioning, the provision of ecosystem services (ES), and the state of biodiversity in RPG (Paruelo et al. 2005, Modernel et al. 2016). This region represents a biodiversity-rich area encompassing more than 550 different species of grass, 450-500 birds, with some endemic species, and a hundred species of terrestrial mammals (Bilenca \& Miñarro 2004; Di Giacomo \& Parera 2008, Azpiroz et al. 2012, Andrade et al. 2018). However, these species are being threatened by LULC changes in the area (Di Giacomo \& Krapovickas 2005, Codesido et al. 2013, Dotta et al. 2015). Based on these and the fact that the RPG are the least protected sub-region in South America (Henwood 2004, Michelson 2009, Baeza \& Paruelo 2020), it highlights the importance of protecting this area in order to conserve and maintain its BES (Baldi \& Paruelo 2008, Modernel et al. 2016, Oyarzabal et al. 2019).

Most of the land is private in the region, belonging to families and corporations, often international (Modernel et al. 2016). LULC transformation is also driven, in turn, by global economic issues (the increase in the prices of commodities) and the availability of new technologies (no-tillage cropping, genetically modified organisms, afforestation know-how, etc.) (Satorre 2005, Trigo 2005, CéspedesPayret et al. 2009). Therefore, land-use policies play a fundamental role in determining LULC dynamics (Lambin et al. 2003, van Meij1 et al. 2006, Brannstrom et al. 2008). These policies can promote or restrain particular crops or types of land management using taxes and regulations (Redo et al. 2012). Internal policies established within a given country are the primary underlying drivers of LULC changes (Geist \& Lambin 2002). Furthermore, political boundaries and biophysical heterogeneity of RPG also influence these trends (Vega et al. 2009).

New strategies should be considered to allow the coexistence of agricultural activities with grassland biodiversity conservation in the RPG. In this study, we applied the IPBES framework (Díaz et al. 2015) as a new lens to approach biodiversity conservation enactments in the RPG. Specifically, we sought to 1) identify the main drivers (direct and indirect) that are affecting the BES in the RPG and link them with the different values and categories defined by IPBES, 2) identify national and international policies related to RPG that affect the drivers underlying the BES, 3) build a conceptual framework for the RPG using the IPBES framework, based on the drivers, values, and policies identified in the previous objectives; 4) and finally, propose policies that could help the co-management of grasslands in this region and halt the rapid loss of BES. 


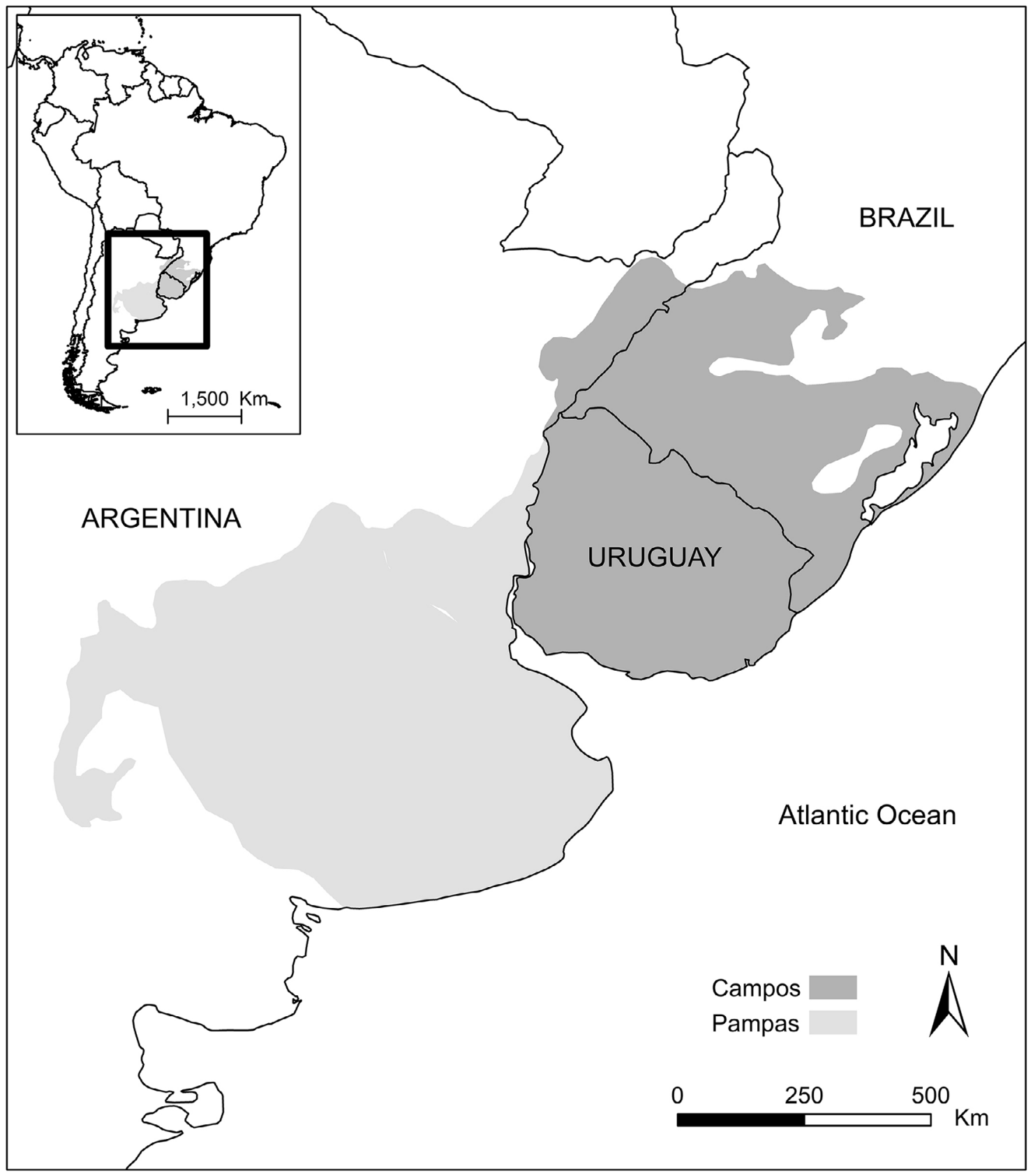

Figure 1. Location of the Río de la Plata Grasslands (RPG) and sub-regions, Pampas and Campos, in Southeastern South America (sensu Soriano et al. 1991).

\section{Material and Methods}

We engaged in a qualitative systematic review approach (FinfgeldConnett \& Johnson 2013) to centralize and consolidate pre-existing knowledge on LULC changes and BES in the RPG.

\section{Scientific literature review: Linking BES with IPBES in the $R P G$}

A literature search was conducted in two steps. First, we performed a Boolean search in Web of Science platform (July 22 $\left.2^{\text {nd }}, 2019\right)$, using the following string of keywords: ("Río de la Plata grasslands" OR "Pampas grasslands" OR "Campos Grasslands") AND ("land use" OR "agriculture" OR "afforestation" OR "pasture" OR "grazing”) AND ("ecosystem services" OR "biodiversity”). To add several papers that did not appear in the first search but were relevant for this study, we performed an ad hoc search using various resources, e.g., other database searches, such as Google Scholar, checked cited literature, etc. Following this procedure, we included different reviews and other articles relevant to the study area. From the selected papers, we chose the ones that were published between 2015 and 2019, because most of the papers before this period were included in the other reviews (e.g. Bilenca \& Miñarro 2004; Modernel et al. 2016). From each one of the selected papers, we extracted the main ES mentioned in the study and the drivers of the loss of the BES (direct and/or indirect). We then organized the information following the 18 categories of the NCP and placed them into the types of contribution (regulating, material, and non-material) (Díaz et al. 2018). 


\section{Review of current policy-based conservation in the RPG}

Current policies for RPG management were reviewed by conducting a systematic search of policies, regulations, and legislation available on official websites for each one of the countries. For our analysis, we identified and selected policies that are exclusively related to issues of BES conservation in RPG. We took into account historical national and regional legislation. Relevant information was extracted, in order to contrast to what extent these policies are addressing the drivers depicted in the scientific literature. We listed applicable laws or initiatives that promoted the LULC changes in RPG and represented the conservation situation within each country. Finally, we described the conservation efforts at an international and national level.

\section{An approach to IPBES conceptual framework}

Based on the key findings of these searches, we developed a conceptual model for the RPG using the IPBES framework (Díaz et al. 2018).

\section{Results}

\section{Scientific papers review: Linking BES with IPBES in RPG}

Based on our literature search, we found that most studies in the region focused on regulating contributions, highlighting material ones, while a few studies considered non-material contributions (Table 1).

Several papers focused on the ecological functions of RPG's biodiversity and the effect that agricultural activities have on them, highlighting and emphasizing nature's intrinsic value. In particular, these studies identify the importance of the RPG as habitat for pollinators (Sabatino et al. 2016, Marrero et al. 2017), and areas of high plant and animal diversity (Modernel et al. 2016). All the studies agree that biodiversity loss is associated with the transformation, homogenization, and perturbation of the habitat. Modernel et al. (2016) described other drivers of biodiversity loss, such as the invasion of exotic species, expansion of crops and implanted pastures, urbanization, and overgrazing. Illegal hunting and zoonotic diseases introduced by exotic species also threaten native species (Bilenca \& Miñarro 2004).

Instrumental values were identified in several publications studying the benefits people can obtain from grasslands and associated biodiversity (Table 1). Goijman et al. (2015) stated that the agricultural intensification is detrimental to birds and their ecological functions, potentially causing a decrease in ES provided by them. For instance, insectivore birds play a role as pest controllers, a valuable ES in agricultural landscapes. Native grasslands provide regulation of water quality and availability, climate regulation, water provision, nutrient cycling, and erosion control (Modernel et al. 2016, Eguren et al. 2018, Villarino et al. 2019). All these benefits are affected by LULC changes, crop type and management, and climate change. Most of these papers reiterate the adverse consequences of climate change and LULC changes in the provision of agricultural products, which highlights the importance of sound and sustainable practices for the economy in the RPG.

Finally, we found that studies on both relational values and non-material contributions are scarce for the RPG (Table 1). Auer et al. (2017) identified agricultural activities that provided cultural benefits based on traditional activities in particular geographical areas.
Furthermore, different aspects of the natural landscape sustained cultural values, giving local people a sense of place and cultural heritage. The authors also stated that although this study is from a small local area, the trends in agriculturalization processes follow a general pattern in the region, and based on socio-ecological similarities along the Pampas, this effect could be found in the entire sub-region (Auer et al. 2017).

Although we made a classification, it is recognized that the NCPs are perceived by people in different ways and each contribution can fit more than one category (Pascual et al. 2017, Díaz et al. 2018).

\section{Review of current policy-based conservation in the RPG}

\subsection{National laws and initiatives that promote the degradation of grasslands}

In Argentina, during the first half of the $20^{\text {th }}$ century, there were cattle ranching and agriculture development under extensive or semi-intensive conditions, which consolidated the crop rotation model with annual pasture and forage (Viglizzo \& Jobbágy 2010). By the 1970s and 1980s, increases in production were correlated to the expansion of cultivated areas over native grasslands and other types of environments (Carreño \& Viglizzo 2007). In fact, between 1960 and 1990, the rate of grain production was six times higher than that of cattle ranching (Sturzenegger 2006). By the 1990s, intensive use of agricultural inputs and technology was prevalently escalating the LULC changes in the region (Viglizzo et al. 2001), while biotechnological innovations allowed an increase in yield per hectare. Technological advances were simultaneous to economic policy reforms that favoured Argentina's agriculture, such as export tax elimination; the reductions in tariff and non-tariff protection on fertilizers, agrochemicals, machinery and irrigation equipment; the deregulation of private economic activities, mainly commercial and financial, which allowed the reductions of agricultural financial marketing costs (Sturzenegger 2006). In 2002, the government announced the application of withholdings to exports primary products, and both agricultural and industrial manufactures (Colomé 2008 ). The tax retentions were by $2015,23 \%$ for wheat, $20 \%$ for corn, and $35 \%$ for soy. In 2016, a new government adopted different measures such as the elimination of withholdings to exports wheat, corn, and meat and a 5\% decrease for soybean retention (MA 2015).

From the mid-1990s, timber production has experienced significant growth driven by legislation that promoted forest plantations. In 1999, a law of Investments in Forestry in Planted Forests $\left(\mathrm{N}^{\mathrm{o}} 25,080\right)$ was promulgated and later expanded in 2019 (Law No 27,487). The aim was to increase the stock from 1.3 to 2 million ha of cultivated forests by 2030, which contributed both to sustainable development goals and the climate change commitments assumed with the Paris Agreement (MAGyP 2018). This law established a regime that promotes investments made in new forestry ventures and the expansion of existing forests. It also favors the initiation of forest industry enterprises and the development of existing ones, as long as the timber supply is increased through the introduction of new forests. The benefits granted are tax stability for at least 30 years, tax benefits, and non-reimbursable economic support which will consist of an amount per hectare, variable by zone, species, and forestry activity. These ventures must comply with the zoning of forestry basins that must respect the territorial planning of native forests established by national law of minimum budgets for 
Table 1. Summary of Nature's Contribution to People (NCP) studied in the Río de La Plata Grasslands (RPG) based on the scientific paper review. The NCP is organized based on the generalizing perspective of the IPBES framework, and 18 reported categories are distinguished (Díaz et al. 2018): 1. Habitat creation and maintenance; 2. Pollination and dispersal of seeds and other propagules; 3. Regulation of air quality; 4. Regulation of climate; 5. Regulation of ocean acidification; 6. Regulation of freshwater quantity, location, and timing; 7. Regulation of freshwater and coastal water quality; 8. Formation, protection, and decontamination of soils and sediments; 9. Regulation of hazards and extreme events; 10. Regulation of detrimental organisms and biological processes; 11. Energy; 12. Food and feed; 13. Materials, companionship, and labor; 14. Medicinal, biochemical and genetic resources; 15. Learning and inspiration; 16. Physical and psychological experiences; 17. Supporting identities and 18. Maintenance of options. The NCP categories are divided into three broad groups depending on the type of contribution they provide to people into Material, Non-material, and Regulating (Díaz et al. 2018). The studied region of each paper is specified: Argentina (ARG), Uruguay (URU), Brazil (BR); the entire region (All).

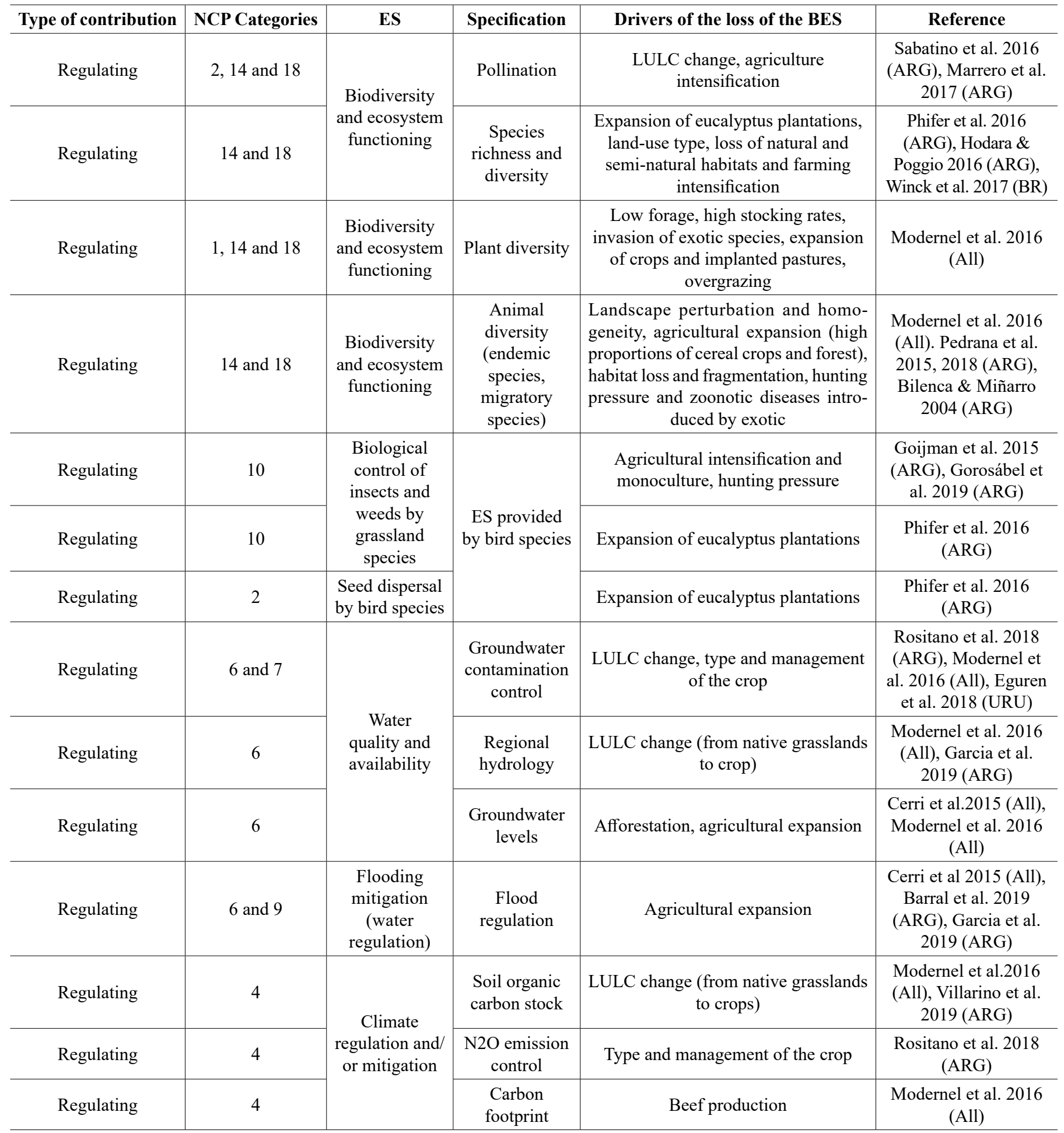


Gorosábel, A. et al.

Continuation...

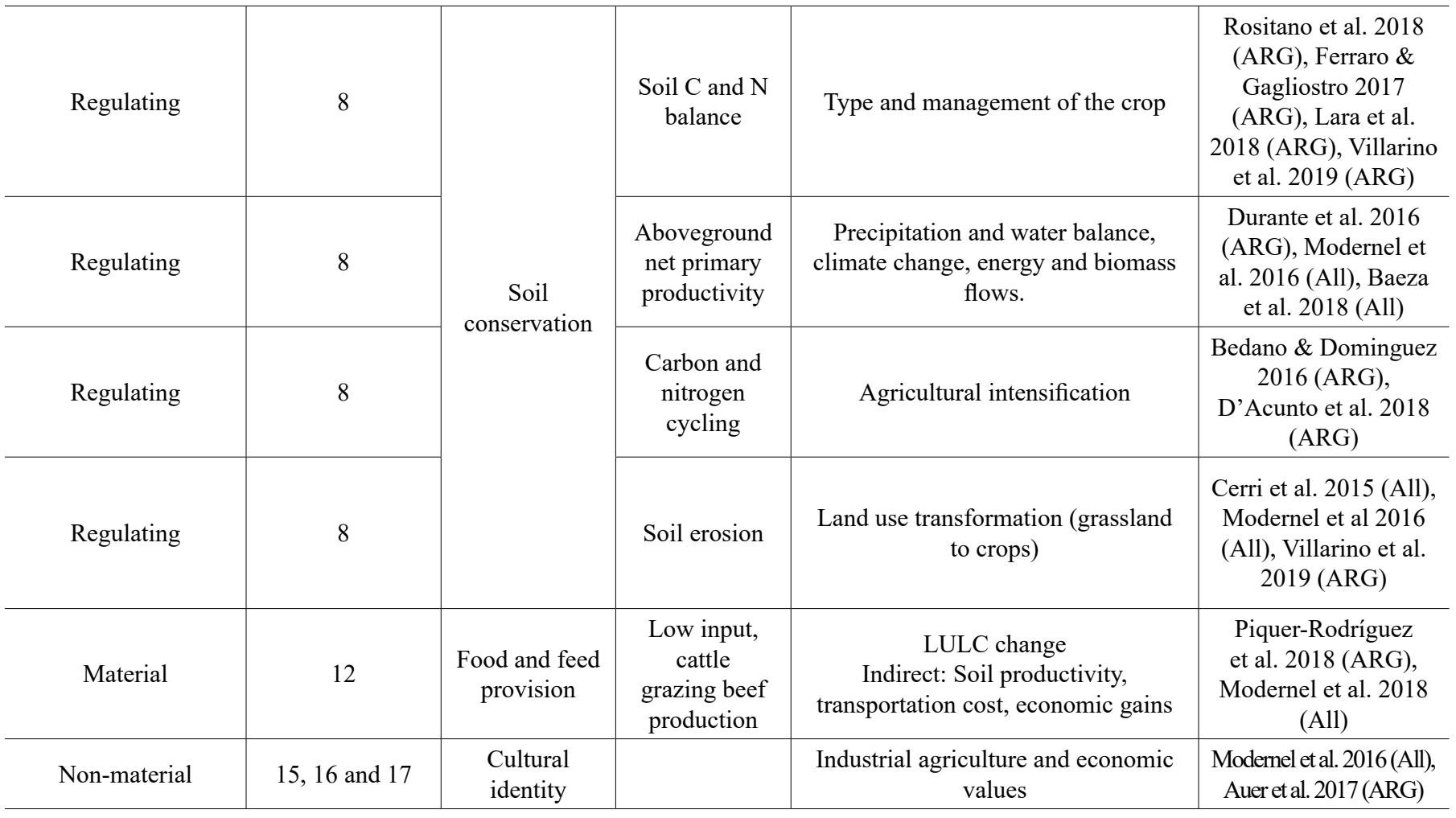

environmental protection of native forests $\left(\mathrm{Law} \mathrm{N}^{\circ} 26,331\right)$. This zoning aims to conserve native forests, but not other native ecosystems.

In Brazil, several policies that favor the expansion of different types of land-use activities have existed for decades. Within these activities are agriculture, mainly corn, soy and wheat crops, afforestation, and cattle ranching. Additionally, policies have been directed to manage productivity in beef cattle in pastures, through the establishment of minimum stocking rates (number of a particular type of animal per unit area). As a result of these policies, in 1970, there were 14,078 million hectares of natural pastures, but by 1996, only 10,524 million hectares remained. An example of cattle management was the project S3CR11 $(1969 / 1970)$, which involved a forage improvement phase of the native grasslands of Rio Grande do Sul (Pillar et al. 2009).

Recently, the National Strengthening Program for Family Farming (PRONAF in Portuguese) was enforced. Although this program contributed socially and economically, it has negative environmental impacts. Grisa \& Schneider (2015) state that in the municipality of Rio Grande do Sul, this program was predominantly oriented towards productive developments based on the use of chemical inputs. It also promotes a specialization in grain production and other agricultural commodities, which has led to the development of environmentally detrimental agricultural production models.

Finally, in Uruguay, internal policies regarding afforestation had a significant impact on the quantity and distribution of LULC changes (Cubbage et al. 2012). In 1987, Forestry Law ( $\left.\mathrm{N}^{\circ} 15,939\right)$, was approved as a commitment to supporting and growing the forestry sector. Its objective was to replace marginal and unprofitable farming and ranching on poor soils with afforestation and pulpwood production to supply mainly European markets (Snoeck et al. 2008). This law identified priority regions for afforestation and provided financial incentives such as subsidies, tax reliefs, and exemptions and targeted loans to investors (Cubbage et al. 2012). These incentives encouraged largescale plantations and forest products manufacturing facilities (Mendell et al. 2007, Redo et al. 2012). Consequently, the tree plantations area in Uruguay increased rapidly, reaching the highest afforestation rate in Latin America between 1988 and 1998 (Mendell et al. 2007, Cubbage et al. 2012). However, in the early to mid-2000s, all incentives were revoked leading to a $24 \%$ decline in plantation areas between 2001-2009 (Redo et al. 2012). More recently forest companies are trying to promote joint ventures with cattle ranchers who own land by leasing their plantations to local farmers, forming silvopastoral systems (Cubbage et al. 2012).

Before the beginning of the century, soybean was not considered an essential crop within other agricultural staples in Uruguay. However, between 2000 and 2009, a soybean production boom exceeded the most dominant crop in the country, wheat, occurring at the expense of the country's herbaceous cover (Redo et al. 2012). Global demand and prices have played an essential role in driving soy expansion post-2002 (Oyhantçabal \& Narbondo 2011). However, price alone cannot account for the sudden expansion, considering that the price was already relatively high in the mid-1990s. For this, it is essential to take into consideration external policies. The soybean export taxes in Argentina had a direct impact on the quantity and distribution of LULC changes in Uruguay (Redo et al. 2012). Between 2002-2013, the soybean area increased from 10,000 ha to 1.2 million ha (Souto 2012). On one hand, this increase was mainly due to the lower land prices and the lack of export taxes in Uruguay; and on the other, high land prices and high agricultural taxes in Argentina introduced in the early 2000s (Redo et al. 2012). 


\subsection{Conservation efforts in RPG at the international level}

At an international level, there are two important initiatives focused on the RPG: (1) The Southern Cone Grassland Alliance (Alianza del Pastizal in Spanish) created in 2006 with the support of BirdLife International and in collaboration with NGOs (non-governmental organizations) from Argentina, Uruguay, Paraguay, and Brazil. This alliance seeks to protect the habitat of migratory birds and grassland diversity in general by working with different stakeholders (cattle ranchers, environmental NGOs, provincial and national governments, and researchers). In 2010, the Southern Cone Grassland Alliance developed a certification label for meat producers who protected $50 \%$ of their grasslands. In 2012, meat produced under this label became available to consumers (Alianza del Pastizal 2019). (2) The 'Official Incentives Project for the Conservation of Natural Grasslands of the Southern Cone of South America' that seeks to protect the BES in the region (Alianza Pastizal 2019). This project began in 2012, and its main goal was to promote an incentive system (payment for ES scheme) for cattle ranchers who carry out conservation management of natural grasslands on their lands (Parera et al. 2012). For this purpose, a technical tool (Grassland Conservation Index) was built to evaluate and quantify the rancher's contribution to grassland conservation, thereby enabling estimation of the amount of their economic compensation. However, objectives were only partially achieved, and in no case, the payments were done (Weyland et al. 2019). One possible reason for this result was that the scheme coincided with the end of the government's mandate and the change in the authorities (Weyland et al. 2019).

\subsection{Conservation efforts in RPG at a national level}

In each country, different policies or private initiatives have been attempted in order to protect biodiversity and the environment of the RPG (Table 2). To date, conservation initiatives in Argentina are mostly driven by NGOs in collaboration with researchers with the goal of boosting sustainable management practices as well as identifying areas for potential conservation (Table 2). Contrary, in recent decades, Brazil has made significant progress to link biodiversity conservation and economic development, which has played an essential role in international discussions related to conservation. The triggering within the Brazilian society of a specific concern regarding the Campos Sulinos appears to be related to two public discussions: the legal prohibition of burning as a practice of management of the fields in the Rio Grande do Sul (established under the State Constitution of 1989) and the debate surrounding the future of the Pampa biome alongside the announcement of extensive plantations of exotic trees for pulp production (Pillar et al. 2009). Finally, in Uruguay, conservation strategies promoted institutional strengthening, participatory research, and good management practices, by the government in an inter-institutional frame and international organizations (Table 2). All of them focus only on this environment, recognizing natural fields as one of the most important assets of the country in terms of biodiversity.

Based on these initiatives, different levels of conservation were reached in each country. Regarding the scientific community consideration, a natural region is adequately protected when at least $10-15 \%$ of the area is protected by law (Burkart 1999, Bertonatti \& Corcuera 2000) but this condition is not met in any country. Argentina protects $1.05 \%$ of the Pampas eco-region (Moreno et al. 2008, Burkart 2006, Sistema de Estadística Ambiental 2019), while Brazil protects
$2.23 \%$ with the integration of federal level protected areas (Bilenca \& Miñarro 2004). In Uruguay, the National System of Protected Areas (SNAP) constitutes approximately $0.98 \%$ of the national territory but with a high representation of specific species and ecosystems for conservation (Ávila et al. 2018, MVOTMA 2019). However, its low connectivity and surrounding landscapes (intensified production systems) are hostile to biodiversity and accentuating their biological isolation.

\section{An approach to applying the IPBES conceptual framework to the RPG}

It is important to note, that as the RPG extend into Argentina, Brazil and Uruguay, the associated values are affected not only by the spatial scale under analysis (local, regional, national or international), but also by micro and macro cultural, social, and political dynamics and complexities.

The conceptual framework we have developed for the RPG (Figure 2) has LULC changes as the main focal point and as the principal direct driver for the grassland BES. Based on our literature and policy review, there is a clear tendency to focus on the material contributions, which are traceable to the meat production history of the area (Viglizzo et al. 2001), as well as a distinct trend to increase crop production and afforestation with various incentives. The identification, valuation, and study of non-material values are scarce (such as learning and inspiration, physical and psychological experiences, and supporting cultural identities). Finally, the regulating contributions are becoming more relevant in the literature, especially in the face of climate change, but there is still a long way to go regarding policy application and implementation. However, in this framework, we emphasize the importance of all three of these interrelated components.

On one hand, LULC changes as the primary direct driver of change in the RPG includes three main elements: cattle grazing, crop production, and afforestation. The framework also articulates the values (NCP categories of IPBES framework) provided by these land uses, as a result of recognizing its social-economic importance. A relevant note regarding LULC changes is that the values provided, and the negative impacts on grasslands can profoundly differ according to the management applied. Traditional uses such as low-density cattle grazing or family farming will be more compatible with conservation concerns related to grasslands; intensive agriculture and afforestation, in turn, would be more detrimental to grassland's BES. Therefore, we assume that the transformations of this landscape are mostly to high-intensity LULC changes with inherent ecological consequences.

On the other hand, we organized the indirect drivers of LULC changes into two groups. The first one integrates technology, climate change, and international commodity prices. Technology, through technological advances, allows increasing productivity per unit area leading to less area needed. Climate change has the capacity to alter (un)suitable land uses and international commodity prices as market forces for higher or lower pressures from specific uses. Therefore, all these are affecting the weight that agricultural activities put on the remaining grasslands. The second group reflects the importance of highlighting the influence of politics and inherent political instability in the LULC changes, but also its integration in the remaining indirect drivers. Lastly, direct and indirect drivers' dynamics are viewed as a two-way relationship. 
Gorosábel, A. et al

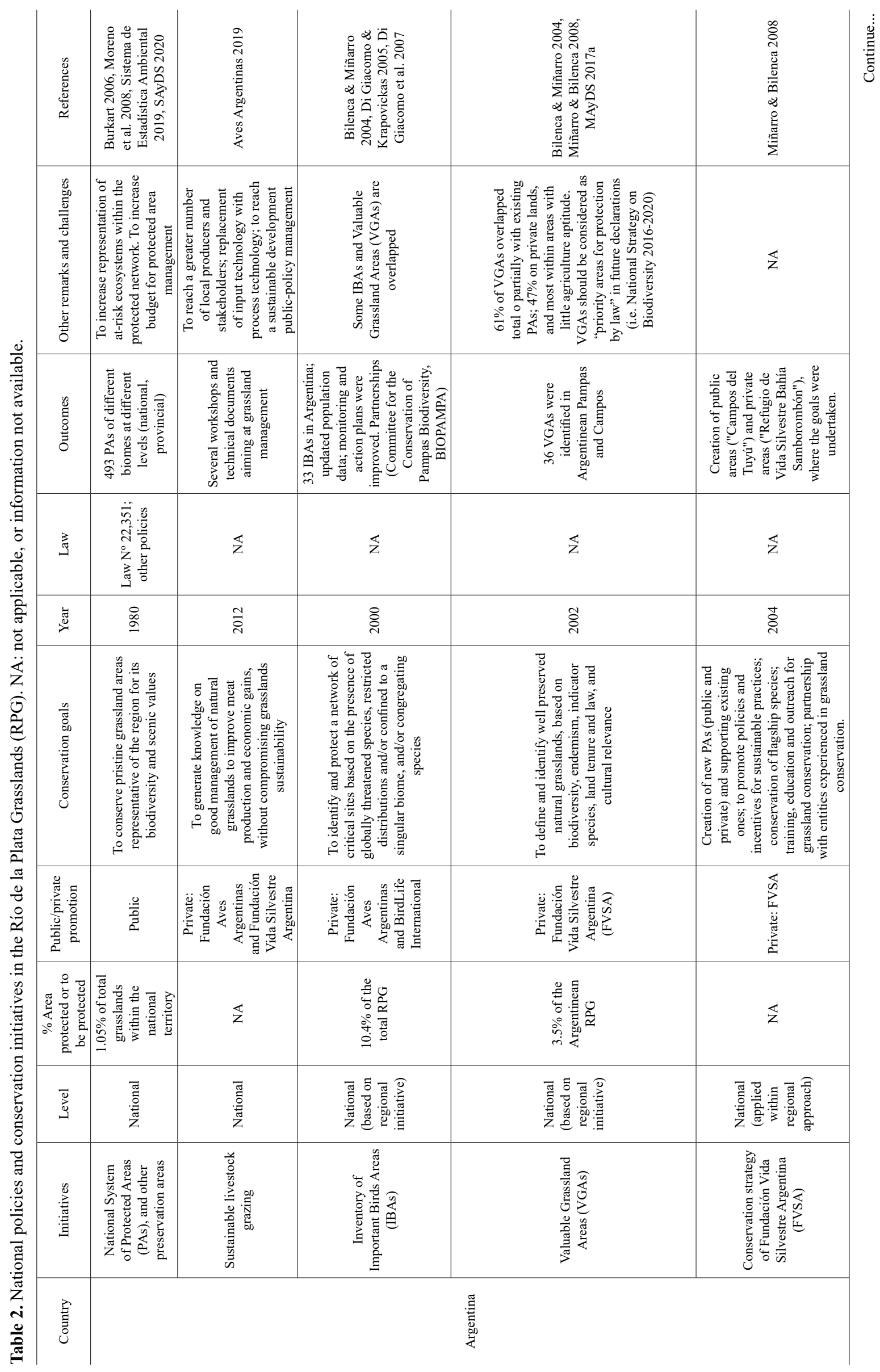


Policy-based conservation for RPG

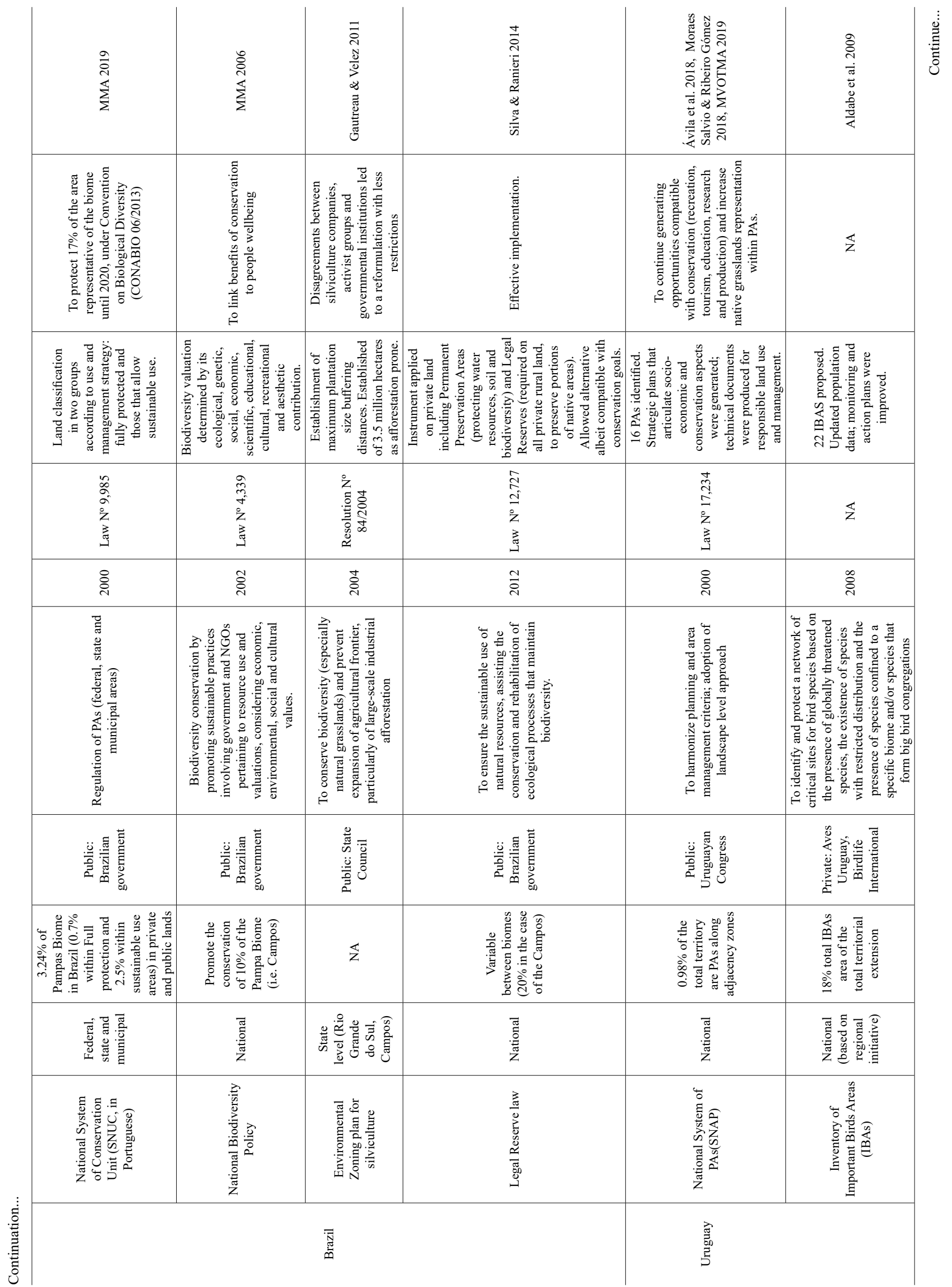


Gorosábel, A. et al.

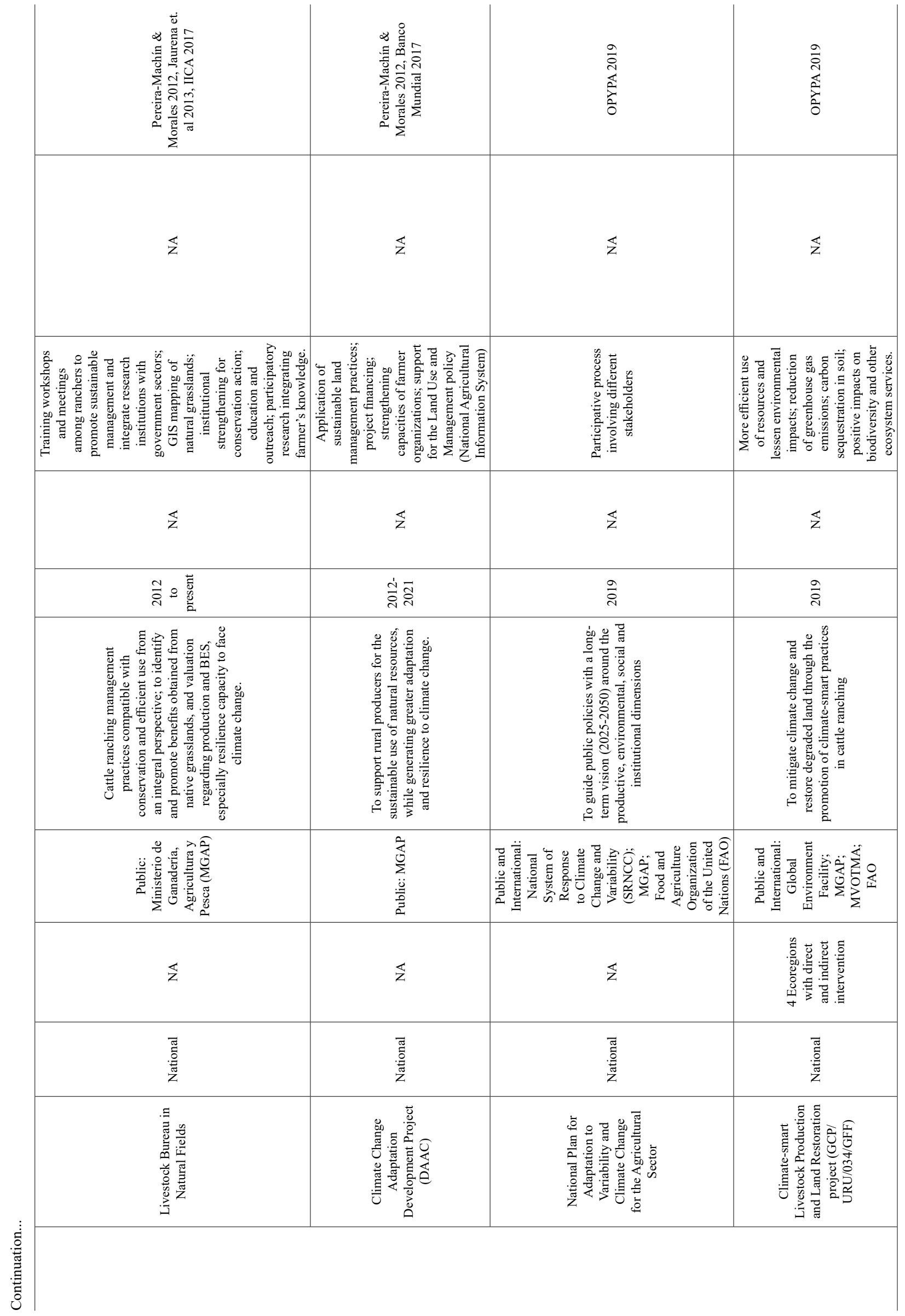




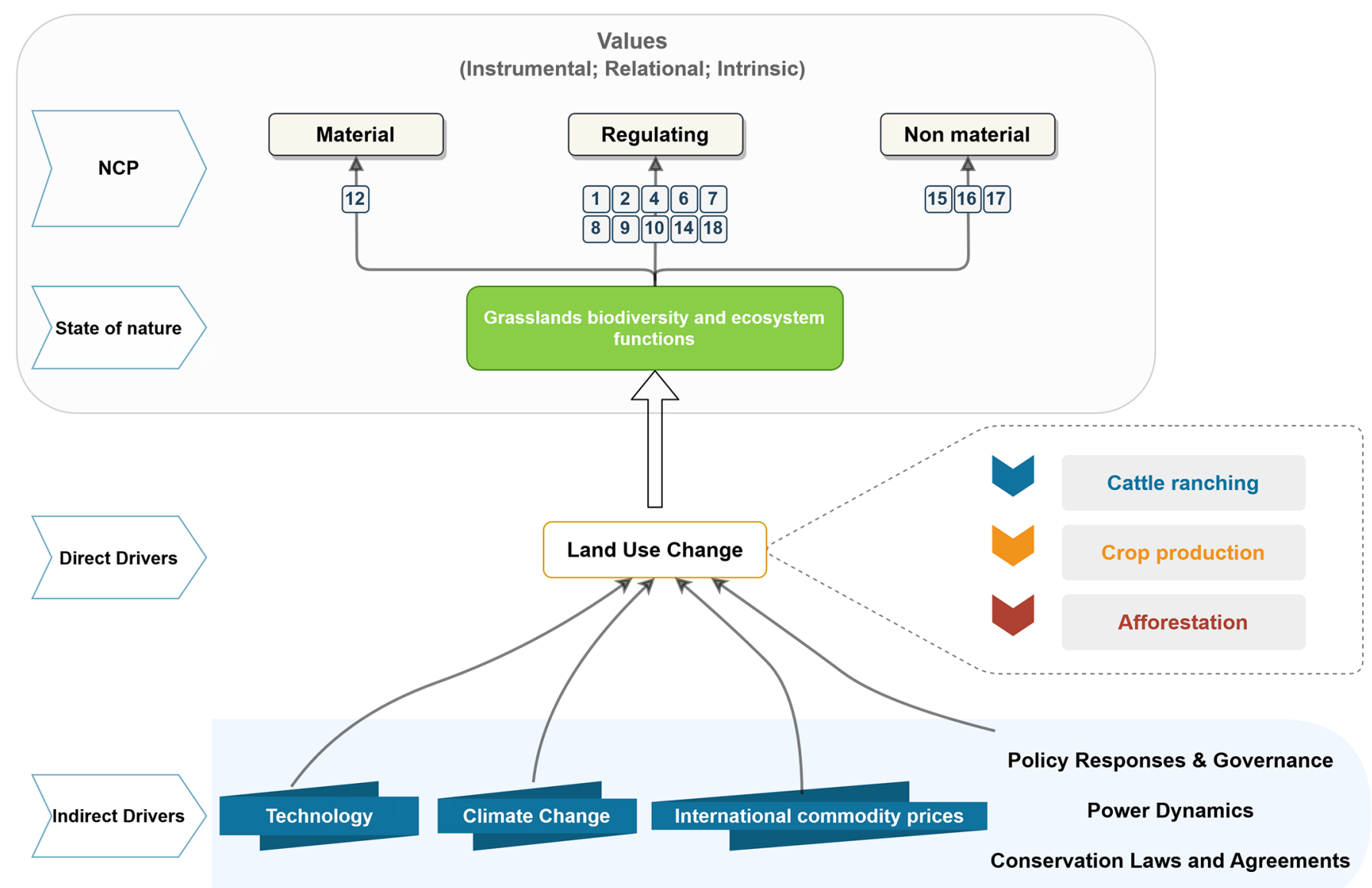

Figure 2. Conceptual framework for policy-based conservation of the Río de la Plata Grasslands (RPG) following the Intergovernmental Science-Policy Platform on Biodiversity and Ecosystem Services (IPBES) and Nature's Contribution to People (NCP) notion.

\section{Discussion}

The main goal of this study was to contribute to policy-based strategies for biodiversity conservation and ecosystem services provision for South America's Río de la Plata Grasslands, within a novel conceptual approach. From our review, we evidenced that the unsustainable practices that have resulted in negative consequences for BES over the RPG are currently still ongoing. We found that the different regions within the RPG share similar drivers of change (e.g. land-use change due to overgrazing, crop expansion, and afforestation, climate change, and invasive species) and are experiencing comparable negative consequences regarding the conservation of BES. Most studies highlighted regulating and material NCPs, while we found scarce information on non-material NCP. Similar results were evidenced by Mastrangelo et al. (2015), showing a tendency to focus on the biophysical processes and patterns of the ES rather than on assessing its cultural component and benefits to people. Thus, the LULC changes have occurred at the expense of the loss and degradation of natural environments, the system's sustainability, and cultural values (Mastrangelo et al. 2015, Modernel et al. 2016, Auer et al. 2017). Consequently, it is essential to develop a regional assessment of the RPG adapted to the cultural, social, political, and economic issues of the region. In addition, a transdisciplinary approach could help strengthen the interface between science and policy-makers while enhancing the participation of different stakeholders.
Current policy approaches for BES conservation differ between regions and countries. Based on our conservation-policy review, we found the pervasive and systemic grassland ecosystem degradation concerning. Although all countries recognize the importance of this biome and consequently express an interest in its conservation, the implementation and execution of plans and actions have been sparse. Lack of action is reflected in the limited inclusion of protection mechanisms in regional and local land planning strategies, as well as in the very low levels of protected-area coverage of native grassland within the RPG.

Policies for the conservation of BES in the study area are uncommon and incipient, particularly in Argentina and Uruguay (Azpiroz \& Rilla Manta 2007, Modernel et al. 2016), while Brazil appears on the lead as far as current existing laws for grassland's BES conservation. To date, most conservation initiatives in Argentina are non-normative and territorial planning that includes grasslands is lacking. The Argentinian legislation considers only native forests as a priority for conservation when it regulates the promotion of productive developments. We propose that different types of biomes should be included, in order to reduce the potential threats to other vulnerable ecosystems. These could help increase the recognition of the grasslands' ecological value and its conservation, from regional to national scales (Bond \& Parr 2010, Overbeck et al. 2007). Thus, there is an urgent need to implement initiatives that establish a minimum proportion of grasslands to be 
protected, with special emphasis on at-risk areas, along with strategic territorial planning initiatives. These could ensure that productive activities do not represent a threat to vulnerable ecosystems, especially where the most natural tracts of grasslands still remain. In Uruguay, a series of governmental initiatives were proposed in the last decades, which aimed at sustainable management of cattle ranching in natural fields and conservation of its BES (Bartesaghi et al. 2015, Ávila et al. 2018). Although there are concrete actions in the conservation of grasslands, it is necessary to create national legislation to regulate and enforce conservation policies. Contrary to these sustainable proposals, a recent law aims at intensifying agricultural production (Irrigation Law, $\left.\mathrm{N}^{\mathrm{o}} 19,553,2017\right)$, which could negatively affect the grassland conservation.

In Argentina and Uruguay, conservation policies are more oriented towards the protection of a few threatened grassland species and their habitats (Di Giacomo et al. 2007, Soutullo et al. 2013, MAyDS 2017b). On the other hand, Brazilian policies for grassland conservation present a more optimistic perspective for the future. Expectations are on the enforcement of the Environmental Rural Registry code, which has the potential to constitute a reserve of preserved native grasslands. The possibility of linking the Permanent Preservation Areas and Legal Reserves should safeguard a minimum of $20 \%$ of the private grassland areas, and those within the governmental protected areas. However, grasslands in southern Brazil are considered a "neglected biome" (Overbeck et al. 2007), since it is not given adequate consideration and protection in comparison to other Brazilian biomes, and where policies focusing on farming intensification pose a significant threat to the BES sustainability of the grassland ecosystem.

We agree with Hoekstra et al. (2005) that conservation efforts should be addressed at large scales, as national and regional perspectives are the scales at which conservation policies will be more effective in halting habitat and biodiversity loss across the RPG (e.g. Di Minin et al. 2017). As previously mentioned, the management of the region has been mainly driven by national policies centered on rural economic development. Nevertheless, there are international initiatives that are applied to RPG conservation, mostly driven by NGOs actors. These initiatives are encouraging, but require institutional support enabled by national political approaches to reach a broad, transnational, and effective conservation outcome. There are several examples of successful multinational conservation efforts that transcend geographical boundaries and work together in pursuit of conservation, such as Natura 2000 network in the European Union through the EU's Birds (79/409/EEC), Habitats Directives (92/43/EEC) and the UN Convention on Biological Diversity. Regarding grassland management and conservation in the RPG, it is possible to address some similarities in comparison with European conservation approaches. Identified threats to European grasslands (Silvia et al. 2008) are in line with the ones found in our case study (EEA 2012). Concerning protected areas, different EU Member States define different approaches toward conservation. In effect, $25 \%$ of the $27 \mathrm{EU}$ terrestrial lands are protected under either Natura 2000 (where human activities must be harmonious with the conservation of sites of natural importance), national designations, or a combination of both. Grasslands ecosystem share was $9.2 \%$ of the total area of protected sites in Europe, while for the total of areas included in Natura 2000, 11\% were classified as grasslands (EEA 2012). Some of the policy proposals for these areas include the promotion of high nature value farmland or payments to farmers for the environmental services provided (Silvia et al. 2008).

Following the IPBES framework and the NCP concept, we sought to link scientific knowledge on biodiversity and ecosystem function, the values for society, and the policies that could promote conservation in the RPG. We concluded that the different regions in the RPG have in common not only the drivers but also the underlined negative consequences regarding the conservation of BES. Therefore, the conceptual framework built in this study is generalizable to the full extent of the RPG. This framework could be used as a tool to communicate the relevance and the benefits to society of preserving native grassland's BES in this region. Also, it could help to focus attention on the consequences of not applying sustainable management, which can result in the direct loss of the long-term productive capacity and resilience of this ecosystem (Foley et al. 2005, MEA 2005). Furthermore, this model would also aid in detecting the lack of information and policies in some areas, and serve as a base model to integrate new information. Lastly, the framework could be useful as a primary input in qualitative or quantitative modelling of relevant socioeconomic scenarios and conservation outcomes (for instance, the Shared Socioeconomic Pathways; O’Neill et al. 2014), identification of policy options for future management (e.g. Anton et al. 2010, Paracchini et al. 2011), and to construct spatial models for synergies or trade-offs between different ecosystem functions and its conflicts (e.g. Zhang et al. 2019b).

\section{Conservation policy proposal}

Taking into consideration the "emerg[ent] biome crisis" (Hoekstra et al. 2005) that temperate grasslands face, and based on the threats identified in this study, we highlight a combination of policy mechanisms for conservation of the RPG. Based on the proposed framework, the following initiatives could enhance and/or maintain the existing biodiversity as well as increase connectivity throughout the RPG. In addition, we associate the different values and NCPs that these policies could enhance. However, we acknowledge that these efforts are not an end but a starting point to reach long-term conservation goals.

First and foremost, an expansion of the natural protected areas in the RPG is crucial. Dinerstein et al. (2019) state that there is a small window of opportunity of 10 years to halt climate change below $1.5^{\circ} \mathrm{C}$ and to prevent 'points of no return' in terms of habitat loss and species extinction. Following this idea, we concur that a higher percentage of the RPG should be under some form of protection. Protection here is understood as defined by the International Union for Conservation of Nature (Dudley 2008). In order to protect all subregions in the RPG, each country could use a combination of the following: (1) establish multiple protected areas through legal mechanisms in zones identified as hotspots for BES, including the creation of buffer zones and natural corridors within agricultural landscapes (e.g. Nin et al. 2016, Schröter et al. 2017) to increase interconnectedness throughout the RPG; (2) Create incentives (in the form of tax breaks or payments for ES) for landowners who allocate part of their properties to grassland conservation (Alianza del Pastizal 2019). (3) Argentina and Uruguay could adapt and implement similar measures to that of Brazil (Environmental Rural Registry) to protect $20 \%$ of each private property.

We are aware that effective grassland biodiversity conservation outcomes cannot be achieved through protected areas alone (Harlio et 
al. 2019). Thus, it is important to take into consideration the connectivity of these conservation areas to minimize landscape fragmentation and its detrimental effect on biodiversity (Batáry et al. 2011). The connectivity of these natural areas is essential to dispersal success, persistence, and genetic diversity of species in fragmented landscapes (Schooley \& Branch 2011). Some of the agri-environment schemes implemented by the European Union's Common Agricultural Policy did not have a positive effect on biodiversity and it was associated with the lack of regional and landscape conservation planning in farmlands (Batáry et al. 2011; Harlio et al. 2019). Looking at the trends of the RPG, there is an increase in cropland areas, so the maintenance of rural roadside could play an important role. Roadsides can host a diverse and representative flora and fauna of the region, supporting their importance as refuges and reservoirs of biodiversity (Saez et al. 2014; Arenas et al. 2017). Herrera et al. (2017) suggested a novel and simple index to assess the conservation status of roadsides that could serve as an initiative to implement in other areas and to take these landscape elements into consideration in decision-making.

Second, the regulation of LULC changes throughout the RPG is fundamental to the long-term conservation of this biome. Existing economic regional bodies such as MERCOSUR (Common Market of South America) could be used to establish biome-wide conservation goals, legislation, and control mechanisms that align with each country's economic growth models (Soutullo \& Gudynas 2006). Such actions could include, but are not limited to, the establishment of national zoning and land use regulation schemes based on socio-economic information and BES hotspots identification (Nin et al. 2016; Di Minin et al. 2017). This process could be expanded to the entire RPG region, and even to larger spatial scales within a multi-biome land-use prioritization approach (i.e. the entire Del Plata Basin; Viglizzo \& Frank 2006). These guidelines could help reach an agreement between countries about land-use policies focusing on particular areas that are crucial for the RPG's biodiversity and ecosystem services provision. This will require control mechanisms that can verify such activities are following and meeting national and regional agreements. Coordinated actions between the involved countries, along with well-defined management objectives and regulations, could represent a key strategy for developing an effective regional network of conservation strategies inside and outside of protected areas (Bicknell et al. 2017; Moraes Salvio \& Ribeiro Gómez 2018).

Lastly, the inclusion of socio-cultural values into all management policies and plans is necessary. The identification and comprehension of the different nature values and worldviews are essential steps to link the NCP and their influence on human well-being. This approach is applicable to initiatives at the science-policy interface in order to obtain sustainable management of the environment (Pascual et al. 2017). Policies that consider stakeholder's welfare based on local and scientific knowledge and allow compatibility between different land uses could support long-term sustainable use of grassland ecosystems (see examples on Pillar et al. 2009). Effective conservation measures must be implemented with the full support of local communities (Modernel et al. 2016). Furthermore, Dujin et al. (2008) identified three major types of values related to protected areas: economic, social and environmental, which presents benefits that can be enjoyed at multiple levels: local, regional, cross-border, international or global benefits, including the public and private sectors (Kettunen et al. 2009).
Protected areas are the cornerstone of conservation, but taking into consideration the economic relevance of the region to each country, biodiversity conservation cannot rely only on those areas. Sustainable conservation also requires policies for managing the entire region, including areas dedicated to agricultural activities, within a regional perspective, and taking into consideration people's outlooks and values (Margules \& Pressey 2000, Tscharntke et al. 2005, Harlio et al. 2019). Following IPBES' aim to promote the conservation and sustainable use of biodiversity, long-term human well-being, and sustainable development, our study addresses the main drivers of change in the RPG. Our conceptual framework can provide an approach to integrate international policies and increase the conservation level of this biome, connecting it with the different grassland values. We are aware of the complexity of these efforts and the implementation of international policies highlighted in this study. However, national and local governments should realize the importance of conserving the RPG and the consequences of not addressing the drivers affecting it.

\section{Acknowledgments}

We thank an anonymous reviewer for helpful comments and suggestions that greatly improved this manuscript. We are indebted to organizers and instructors from the "São Paulo School of Advanced Science on Scenarios and Modelling on Biodiversity and Ecosystem Services to Support Human Well-being" (SPSAS) for providing us with the tools and inspiration to embark on this project, and the São Paulo Research Foundation (FAPESP) for funding the training, as well as attendance for many of us. We also want to thank Hamza Briak and Maíra Formis de Oliveira in particular, and all peer SPSAS attendees in general, for helpful insights and valuable interactions that enriched our thought process and earlier draft versions. Lastly, authors acknowledge various sources of funding: CONICET (AG), CONICET and UNC (LE); FCT PT/BD/142963/2018 (LFL); ANII Uruguay and BIOS2 Program (JAML); The Rufford Foundation for research project 27153-1 in Nigeria (AAA); ANID PIA/BASAL FB0002 (CRR); Nippon Foundation, Nereus Program (MAO).

\section{Author Contributions}

Antonella Gorosábel: Conceptualization, Formal analysis, Investigation, Methodology, Writing-original draft, and Writing-review \& editing.

Lucrecia Estigarribia: Conceptualization, Formal analysis, Investigation, Methodology, Writing-original draft, and Writing-review \& editing.

Luis Filipe Lopes: Conceptualization, Formal analysis, Investigation, Methodology, Writing-original draft, and Writing-review \& editing.

Ana María Martínez: Conceptualization, Formal analysis, Investigation, Methodology, Writing-original draft, and Writing-review \& editing.

Juan Andrés Martínez-Lanfranco: Conceptualization, Formal analysis, Investigation, Methodology, Writing-original draft, and Writing-review \& editing.

Carla Rivera-Rebella: Conceptualization, Formal analysis, Investigation, Methodology, and Writing-original draft. 
Ademola Andrew Adenle: Conceptualization, Formal analysis, Investigation, and Methodology.

Muhammed A. Oyinlola: Conceptualization, Formal analysis, Investigation, Methodology, Writing-original draft, and Writing-review \& editing.

\section{Conflicts of Interest}

The authors declare that they have no conflict of interest related to the publication of this manuscript.

\section{References}

AIZEN, M.A., GARIBALDI, L.A. \& DONDO, M. 2009. Expansión de la soja y diversidad de la agricultura argentina. Ecol. Austral 19(1):45-54.

ALDABE, J., ROCCA, P. \& CLARAMUNT, S. 2009. Uruguay. In Important Bird Areas Americas - Priority sites for biodiversity conservation (C. Devenish, D.F. Díaz Fernández, R.P. Clay, I. Davidson \& I. Yépez Zabala, ed.) BirdLife International (BirdLife Conservation Series No. 16), Quito, Ecuador, p.383-392.

ALIANZA DEL PASTIZAL. 2019. Lifeline. www.alianzadelpastizal.org/en/ institucional/presentacion/ (last access in 05/08/2019).

ANDRADE, B.O., MARCHESI, E., BURKART, S., SETUBAL, R.B., LEZAMA, F., PERELMAN, S., SCHNEIDER, A.A., TREVISAN, R., OVERBECK, G.E. \& BOLDRINI, I.I. 2018. Vascular plant species richness and distribution in the Río de la Plata grasslands. Bot. J. Linn. Soc. 188(3):250-256.

ANTON, C., YOUNG, J., HARRISON, P.A., MUSCHE, M., BELA, G., FELD, C.K., HARRINGTON, R., HASLETT, J.R., PATAKI, G., ROUNSEVELL, M.D.A., SKOURTOS, M., SOUSA, J.P., SYKES, M.T., TINCH, R., VANDEWALLE, M., WATT, A. \& SETTELE, J. 2010. Research needs for incorporating the ecosystem service approach into EU biodiversity conservation policy. Biodivers. Conserv. 19(10):2979-2994.

ARENAS, J.M., ESCUDERO, A., MOLA, I. \& CASADO, M.A. 2017. Roadsides: an opportunity for biodiversity conservation. Appl. Veg. Sci. 20(4):527-537.

AUER, A., MACEIRA, N. \& NAHUELHUAL, L. 2017. Agriculturisation and trade-offs between commodity production and cultural ecosystem services: A case study in Balcarce County. J. Rural Stud. 5388-101.

AVES ARGENTINAS. 2019. Kit de buenas prácticas ganaderas. https://www. avesargentinas.org.ar/kit-de-buenas-pr\%C3\%A1cticas-ganaderas (last access in 17/02/2020)

ÁVILA, S., BARTESAGHI, L., BERGÓS, F., ERMAN, D., FERNÁNDEZ, A., HORTA, S., MEDINA, S., MEJÍA, P., MONTEQUÍN, R., PINEDA, G., SALAZAR, A., SCARLATO, G. \& TRONCOSO, A. 2018. Primera década del SNAP. Sistema Nacional de Áreas Protegidas.Ministerio de Vivienda Ordenamiento Territorial y Medio Ambiente, Montevideo.

AZPIROZ, A.B., ALFARO, M. \& JIMÉNEZ, S. 2012. Lista roja de las aves del Uruguay: una evaluación del estado de conservación de la avifauna nacional con base en los criterios de la Unión Internacional para la Conservación de la Naturaleza. Dirección Nacional de Medio Ambiente, Montevideo.

AZPIROZ, A.B. \& RILLA MANTA, F. 2007. Biodiversity and conservation in the Bañados del Este, southeastern Uruguay. In Proceedings of the waterbirds around the world conference (G.C. Boere, C.A. Galbraith \& D.A. Stroud, eds). Edinburgh, UK, p.186-187.

BAEZA, S. \& PARUELO, J.M. 2018. Spatial and temporal variation of human appropriation of net primary production in the Rio de la Plata grasslands. ISPRS J. Photogramm. Remote Sens. 145:238-249.

BAEZA, S. \& PARUELO, J.M. 2020. Land Use/Land Cover Change (20002014) in the Rio de la Plata Grasslands: An Analysis Based on MODIS NDVI Time Series. Remote Sens. 12(3):381.

BALDI, G., GUERSCHMAN, J.P. \& PARUELO, J.M. 2006. Characterizing fragmentation in temperate South America grasslands. Agric. Ecosyst. Environ. 116(3-4):197-208.
BALDI, G. \& PARUELO, J.M. 2008. Land-use and land cover dynamics in South American Temperate grasslands. Ecol. Soc. 13(2):6.

BANCO MUNDIAL. 2017. Más productores rurales uruguayos hacen frente al cambio climático. https://www.bancomundial.org/es/news/pressrelease/2017/11/30/productores-rurales-uruguay-cambio-climatico (last access in 17/02/2020).

BARRAL, M.P., LATERRA, P. \& MACEIRA, N. 2019. Flood mitigation ecosystem service in landscapes of Argentina's Pampas: identifying winning and losing farmers. J. Environ. Manage. 240:168-176.

BARTESAGHI, L., SALAZAR, A., ÁVILA, S., TRONCOSO, A., MEJÍA, P., MELLO, A.L., HOFFMANN, E., SOSA, B., RODRÍGUEZ, A. \& PIÑEIRO, C. 2015. Plan Estratégico 2015-2020. Sistema Nacional de Áreas Protegidas de Uruguay. Ministerio de Vivienda, Ordenamiento Territorial y Medio Ambiente e Instituto de Investigaciones Biológicas Clemente EsTable (IIBCE), Montevideo.

BATÁRY, P., BÁLDI, A., KLEIJN, D. \& TSCHARNTKE, T. 2011. Landscapemoderated biodiversity effects of agri-environmental management: A metaanalysis. Proc. R. Soc. B Biol. Sci. 278(1713):1894-1902.

BEDANO, J.C. \& DOMÍNGUEZ, A. 2016. Large-scale agricultural management and soil meso- and macrofauna conservation in the Argentine Pampas. Sustain. 8(7):653.

BERTONATTI, C. \& CORCUERA, J. 2000. Situación ambiental argentina 2000. Fundación Vida Silvestre Argentina, Buenos Aires.

BICKNELL, J.E., COLLINS, M.B., PICKLES, R.S.A., MCCANN, N.P., BERNARD, C.R., FERNANDES, D.J., MILLER, M.G.R., JAMES, S.M., WILLIAMS, A.U., STRUEBIG, M.J., DAVIES, Z.G. \& SMITH, R.J. 2017. Designing protected area networks that translate international conservation commitments into national action. Biol. Conserv. 214:168-175.

BILENCA, D. \& MIÑARRO, F. 2004. Identificación de áreas valiosas de pastizales en las pampas y campos Argentinos, Uruguay y sur de Brasil (AVPs). Fundación Vida Silvestre. Buenos Aires.

BOND, W.J. \& PARR, C.L. 2010. Beyond the forest edge: Ecology, diversity and conservation of the grassy biomes. Biol. Conserv. 143(10):2395-2404.

BRANNSTROM, C., JEPSON, W., FILIPPI, A.M., REDO, D., XU, Z. \& GANESH, S. 2008. Land change in the Brazilian Savanna (Cerrado), 19862002: Comparative analysis and implications for land-use policy. Land use policy 25(4):579-595.

BURKART, R. 1999. Conservación de la biodiversidad en bosques naturales productivos del subtrópico argentino. In Biodiversidad y Uso de la Tierra. Conceptos y ejemplos de Latinoamérica (S.D. Mateucci, O.T. Solbrig, J. Morello \& G. Halffter, eds). Eudeba, Buenos Aires, p.131-174.

BURKART, R. 2006. Las áreas protegidas de la Argentina. In: La situación ambiental argentina 2005 (A. Brown, U. Martínez Ortíz, M. Acerbi \& J. Corcuera, eds.). Fundación Vida Silvestre Argentina. Buenos Aires, p.399-403.

CARBUTT, C., TAU, M., ESCOTT, B. \& STEPHENS, A. 2011. The conservation status of temperate grasslands in southern Africa. Grassroots 11(1):17-23.

CARREÑO, L.V. \& VIGLIZZO, E.F. 2007. Provisión de servicios ecológicos y gestión de los ambientes rurales en Argentina. Ediciones INTA, Buenos Aires, Argentina.

CERRI, C.E.P., LA SCALA Jr, N., VICTORIA, R.L., QUIROGA, A. \& NOELLEMEYER, E. 2015. Managing soil carbon for multiple ecosystem benefits - Positive examples: Latin America (Brazil and Argentina). In Soil Carbon: Science, Management and Policy for Multiple Benefits (S.A. Banwart, E. Noellemeyer \& E. Milne, eds). CAB International, p.277-286.

CÉSPEDES-PAYRET, C., PIÑEIRO, G., ACHKAR, M., GUTIERREZ, O. \& PANARIO, D. 2009. The irruption of new agro-industrial technologies in Uruguay and their environmental impacts on soil, water supply and biodiversity: A review. Int. J. Environ. Heal. 3(2):175-197.

CODESIDO, M., GONZÁLEZ-FISCHER, C.M. \& BILENCA, D.N. 2013. Landbird Assemblages in Different Agricultural Landscapes: A Case Study in the Pampas of Central Argentina. Condor 115(1):8-16.

COLOMÉ, R.A. 2008. Sobre política agraria Argentina en el período 1933-2007. Rev. Econ. y Estadística 46(1):108-133. 
CROSSMAN, N.D., BRYAN, B.A., DE GROOT, R.S., LIN, Y.P. \& MINANG, P.A. 2013. Land science contributions to ecosystem services. Curr. Opin. Environ. Sustain. 5(5):509-514.

CUBBAGE, F., BALMELLI, G., BUSSONI, A., NOELLEMEYER, E., PACHAS, A.N., FASSOLA, H., COLCOMBET, L., ROSSNER, B., FREY, G., DUBE, F., DE SILVA, M.L., STEVENSON, H., HAMILTON, J. \& HUBBARD, W. 2012. Comparing silvopastoral systems and prospects in eight regions of the world. Agrofor. Syst. 86(3):303-314.

D'ACUNTO, L., ANDRADE, J.F., POGGIO, S.L. \& SEMMARTIN, M. 2018. Diversifying crop rotation increased metabolic soil diversity and activity of the microbial community. Agric. Ecosyst. Environ. 257:159-164.

DÍAZ, S. et al. 2015. The IPBES Conceptual Framework - connecting nature and people. Curr. Opin. Environ. Sustain. 141-16.

DÍAZ, S. et al. 2018. Assessing nature's contributions to people. Science. 359(6373):270-272.

DI GIACOMO, A.S., DE FRANCESCO, M.V. \& COCONIER, E.G. 2007. Áreas importantes para la conservación de las aves en Argentina. Sitios prioritarios para la conservación de la biodiversidad. Temas de Naturaleza y Conservación. Aves Argentinas/Asociación Ornitológica del Plata. Buenos Aires.

DI GIACOMO, A.S. \& PARERA, A.F. 2008. 20 áreas prioritarias para la conservación de las aves migratorias neárticas en los pastizales del cono sur de Sudamérica. Aves Argentinas / Asociación Ornitológica del Plata, Buenos Aires.

DINERSTEIN, E., VYNNE, C., SALA, E., JOSHI, A.R., FERNANDO, S., LOVEJOY, T.E., MAYORGA, J., OLSON, D., ASNER, G.P., BAILLIE, J.E.M., BURGESS, N.D., BURKART, K., NOSS, R.F., ZHANG, Y.P., BACCINI, A., BIRCH, T., HAHN, N., JOPPA, L.N. \& WIKRAMANAYAKE, E. 2019. A Global Deal for Nature: Guiding principles, milestones, and targets. Sci. Adv. 5(4):1-18.

DOTTA, G., PHALAN, B., SILVA, T.W., GREEN, R. \& BALMFORD, A. 2015. Assessing strategies to reconcile agriculture and bird conservation in the temperate grasslands of South America. Conserv. Biol. 30(3):618-627.

DUDLEY, N. 2008. Guidelines for applying protected area management categories. International Union for Conservation of Nature Publications Services Gland, Switzerland.

DUJIN, A., MARESCA, B., MORDET, X. \& PICARD, R. 2008. La valeur économique et sociale des espaces naturels protégés. Cah. Rech 247.

DURANTE, M., PIÑEIRO, G., IRISARRI, J.G.N. \& OESTERHELD, M. 2016 Primary Production of Lowland Natural Grasslands and Upland Sown Pastures Across a Narrow Climatic Gradient. Ecosystems 20(3):543-552.

EEA. 2012. Protected areas in Europe - an overview. EEA Report No 5/2012. European Environment Agency. Copenhagen.

EGUREN, G., RIVAS-RIVERA, N., GARCÍA, C., BÖCKING, B. \& BANDEIRA, S. 2018. Water quality index for agricultural systems in Northwest Uruguay. Environ. Monit. Assess. 190(12):710.

ELLIS, E.C., PASCUAL, U. \& MERTZ, O. 2019. Ecosystem services and nature's contribution to people: negotiating diverse values and trade-offs in land systems. Curr. Opin. Environ. Sustain. 38:86-94.

FAO. 2014. FAO statistical databases FAOSTAT. http://faostat3.fao.org/ (last access in 11/10/2019)

FERRARO, D.O. \& GAGLIOSTRO, M. 2017. Trade-off assessments between environmental and economic indicators in cropping systems of Pampa region (Argentina). Ecol. Indic. 83:328-337.

FINFGELD CONNETT, D. \& JOHNSON, E.D. 2013. Literature Search Strategies for Conducting Knowledge-building and Theory-generating Qualitative Systematic Reviews: Discussion Paper. J. Adv. Nurs. 69(1):194-204

FOLEY, J.A., BARFORD, C., MONFREDA, C., KUCHARIK, C.J., HOWARD, E.A., CHAPIN, F.S., BONAN, G., ASNER, G.P., DAILY, G.C., GIBBS, H.K., PRENTICE, I.C., PATZ, J.A., HELKOWSKI, J.H., COE, M.T., RAMANKUTTY, N., SNYDER, P.K., DEFRIES, R., CARPENTER, S.R. \& HOLLOWAY,T. 2005. Global Consequences of Land Use. Science. 309(5734):570-574.
GANG, C., ZHOU, W., CHEN, Y., WANG, Z., SUN, Z., LI, J., QI, J. \& ODEH, I. 2014. Quantitative assessment of the contributions of climate change and human activities on global grassland degradation. Environ. Earth Sci. 72(11):4273-4282.

GARCÍA, G.A., GARCÍA, P.E., ROVERE, S.L., BERT, F.E., SCHMIDT, F., MENÉNDEZ, Á.N., NOSETTO, M.D., VERDIN, A., RAJAGOPALAN, B., ARORA, P. \& PODESTÁ, G.P. 2019. A linked modelling framework to explore interactions among climate, soil water, and land use decisions in the Argentine Pampas. Environ. Model. Softw. 111459-471.

GAUTREAU, P. \& VÉLEZ, E. 2011. Strategies of environmental knowledge production facing land use changes: Insights from the silvicultural zoning plan conflict in the Brazilian state of Rio grande do sul. CyberGeo Eur. J. Geogr. Eur. J. Geogr. 1-32.

GEIST, H.J. \& LAMBIN, E.F. 2002. Proximate Causes and Underlying Driving Forces of Tropical Deforestation. Bioscience 52(2):143.

DI GIACOMO, A.S. \& KRAPOVICKAS, S. 2005. Conserving the Grassland Important Bird Areas (IBAs) of Southern South America: Argentina, Uruguay, Paraguay, and Brazil. USDA For. Sevice 191:1243-1249.

GOIJMAN, A.P., CONROY, M.J., BERNARDOS, J.N. \& ZACCAGNINI, M.E. 2015. Multi-season regional analysis of multi-species occupancy: Implications for bird conservation in agricultural lands in east-central Argentina. PLoS One 10(6): e0130874.

GOROSÁBEL, A., PEDRANA, J., BERNAD, L., CABALLERO, V.J., MUÑOZ, S.D. \& MACEIRA, N.O. 2019. Evaluating the impacts and benefits of sheldgeese on crop yields in the Pampas region of Argentina: A contribution for mitigating the conflicts with agriculture. Agric. Ecosyst. Environ. 279:33-42.

GRISA, C. \& SCHNEIDER, S. 2015. Políticas públicas de desenvolvimento rural no Brasil. Editora da UFRGS,Porto Alegre.

HANNAH, L., CARR, J.L. \& LANKERANI, A. 1995. Human disturbance and natural habitat: a biome level analysis of a global data set. Biodivers. Conserv. 4(2):128-155.

HARLIO, A., KUUSSAARI, M., HEIKKINEN, R.K. \& ARPONEN, A. 2019. Incorporating landscape heterogeneity into multi-objective spatial planning improves biodiversity conservation of semi-natural grasslands. J. Nat. Conserv. 49:37-44.

HENWOOD, W.D. 2004. The protection of temperate grasslands: A global perspective. In Proceedings of the 7th Prairie Conservation and Endangered Species Conference (G.C. Trottier, E. Anderson \& M. Steinhilber, eds.). Provincial Museum of Alberta, Calgary, p.21-29.

HERRERA, L.P., SABATINO, M.C., JAIMES, F.R. \& POGGIO, S.L. 2017. Una propuesta para valorar el estado de conservación de los bordes de caminos rurales en el sudeste bonaerense. Ecol. Austral 27(3):403-414.

HODARA, K. \& POGGIO, S.L. 2016. Frogs taste nice when there are few mice: Do dietary shifts in barn owls result from rapid farming intensification? Agric. Ecosyst. Environ. 23042-46.

HOEKSTRA, J.M., BOUCHER, T.M., RICKETTS, T.H. \& ROBERTS, C. 2005. Confronting a biome crisis: Global disparities of habitat loss and protection. Ecol. Lett. 8(1):23-29.

IICA. 2017. Instituto Interamericano de Cooperación para la Agricultura. IICA y la MGCN apostando a la conservación del ecosistema natural.. https:// www.iica.int/es/prensa/noticias/iica-y-la-mgcn-apostando-la-conservaciondel-ecosistema-campo-natural (last access in 17/02/2020).

JAURENA, M., FORMOSO, D., GÓMEZ MILLER, R. \& REBUFFO, M. 2013. Campo Natural: Patrimonio del país y fundamento de la estabilidad productiva de la ganadería. Revista INIA 32:30-35.

KETTUNEN, M., BASSI, S., GANTIOLER, S. \& TEN BRINK, P. 2009. Assessing Socio-economic benefits of Natura 2000 - A Toolkit for Practitioners. Output of the European Commission project Financing Natura 2000: Cost estimate and benefits of Natura 2000 (Contract No.: 070307/2007/484403/MAR/B2). Institute for European Environmental Policy (IEEP), Brussels.

LAMBIN, E.F., GEIST, H.J. \& LEPERS, E. 2003. Dynamics of Land-Use and Land-Cover CHange in Tropical Regions. Annu. Rev. Environ. Resour. 28(1):205-241. 
LARA, B., GANDINI, M., GANTES, P. \& MATTEUCCI, S.D. 2018. Regional patterns of ecosystem functional diversity in the Argentina Pampas using MODIS time-series. Ecol. Inform. 43:65-72.

MA. 2015. Ministerio de Agroindustria. Decreto 133/2015. https://www. boletinoficial.gob.ar/detalleAviso/primera/138329/20151217 (last access in 03/02/2020)

MAGyP. 2018. Ministerio de Agricultura, Ganadería y Pesca. Sancionaron la prórroga de la Ley 25.080 "de inversiones para los bosques cultivados". https://www.argentina.gob.ar/noticias/sancionaron-la-prorroga-de-la-ley25080-de-inversiones-para-los-bosques-cultivados (last access 15-08-2019)

MARGULES, C.R. \& PRESSEY, R.L. 2000. Systematic conservation planning. Nature 405(6783):243-253

MARRERO, H.J., TORRETTA, J.P., VÁZQUEZ, D.P., HODARA, K. \& MEDAN, D. 2017. Exotic plants promote pollination niche overlap in an agroecosystem. Agric. Ecosyst. Environ. 239304-309.

MASTRANGELO, M.E., WEYLAND, F., HERRERA, L.P., VILLARINO, S.H., BARRAL, M.P. \& AUER, A.D. 2015. Ecosystem services research in contrasting socio-ecological contexts of Argentina: Critical assessment and future directions. Ecosyst. Serv. 1663-73.

MAyDS. 2017a. Ministerio de Ambiente y Desarrollo SustenTable de la República Argentina. "Estrategia Nacional de Biodiversidad y Plan de Acción 2016-2020". https://www.argentina.gob.ar/ambiente/biodiversidad/ estrategianacional (last access in 08/10/2019)

MAyDS. 2017b. Ministerio de Ambiente y Desarrollo SustenTable de la República Argentina. "Plan de acción extinción cero". https://www.argentina.gob.ar/ ambiente/biodiversidad/extincioncero (last access in 08/10/2019)

MENDELL, B., MORALES, V., BENNADJI, Z., MORENO, A. \& SIRY, J. 2007. Financing Uruguay's forestry sector: Survey and case study. J. For. 105(3):125-130.

MEA. MILLENNIUM ECOSYSTEM ASSESSMENT. 2005. Ecosystems and Human Well-being: Synthesis. Island Pre ed. Washington DC.

MICHELSON, A. 2009. Report on the First South American Workshop for the World Temperate Grasslands Conservation Initiative: defining the South American Strategy. https://www.iucn.org/sites/dev/files/import/downloads/ grasslandsworkshopoct08.pdf (last access 14/10/2019)

MIÑARRO, F. \& BILENCA, D. 2008. The Conservation Status of Temperate Grasslands in Central Argentina. Fundación Vida Silvestre. Buenos Aires.

DI MININ, E., SOUTULLO, A., BARTESAGHI, L., RIOS, M., SZEPHEGYI, M.N. \& MOILANEN, A. 2017. Integrating biodiversity, ecosystem services and socio-economic data to identify priority areas and landowners for conservation actions at the national scale. Biol. Conserv. 20656-64.

MMA - MINISTÉRIO DO MEIO AMBIENTE - Secretaria de Biodiversidade e Florestas. 2006. Diretrizes e Prioridades do Plano de Ação para Implementação da Política Nacional da Biodiversidade, Brasília.

MMA - MINISTÉRIO DO MEIO AMBIENTE. Cadastro Nacional de Unidades de Conservação - $2^{\circ}$ Semestre 2019. https://www.mma.gov.br/areasprotegidas/cadastro-nacional-de-ucs.html (last access in 12/02/2020)

MODERNEL, P., ROSSING, W.A.H., CORBEELS, M., DOGLIOTTI, S., PICASSO, V. \& TITTONELL, P. 2016. Land use change and ecosystem service provision in Pampas and Campos grasslands of southern South America. Environ. Res. Lett. 11(11):1-22.

MORAES SALVIO, G.M. \& RIBEIRO GOMES, C. 2018. Protected area systems in South American countries. Floresta e Ambient. 25(4): e20171134.

MORENO, D., CARMINATI, A., MACHAÍN, N. \& ROLDÁN, M. 2008. Reseña sobre las reservas privadas en la Argentina. In Voluntad de conservar. Experiencias seleccionadas de conservación por la Sociedad civil en Iberoamérica (C.M. Chacón, ed.). The Nature Conservancy y la Fundación Biodiversidad, p.7-33.

MVOTMA. 2019. MINISTERIO DE VIVIENDA Y ORDENAMIENTO TERRITORIAL Y MEDIO AMBIENTE. Áreas protegidas. http://www. mvotma.gub.uy/ambiente/conservacion-de-ecosistemas-y-biodiversidad/ areas-protegidas/snap(last access in 13/10/2019)

NAGENDRA, H., REYERS, B. \& LAVOREL, S. 2013. Impacts of land change on biodiversity: Making the link to ecosystem services. Curr. Opin. Environ. Sustain. 5(5):503-508.
NIN, M., SOUTUlLO, A., RODRÍGUEZ-GALLEGO, L. \& DI MININ, E. 2016. Ecosystem services-based land planning for environmental impact avoidance. Ecosyst. Serv. 17172-184.

O'MARA, F.P. 2012. The role of grasslands in food security and climate change. Ann. Bot. 110(6):1263-1270.

O'NEILL, B.C., KRIEGLER, E., RIAHI, K., EBI, K.L., HALLEGATTE, S., CARTER, T.R., MATHUR, R. \& VAN VUUREN, D.P. 2014. A new scenario framework for climate change research: The concept of shared socioeconomic pathways. Clim. Change 122(3):387-400.

OYARZABAL, M., ANDRADE, B., PILLAR, V.D. \& PARUELO, J. 2019. Temperate Subhumid Grasslands of Southern South America. In Reference Module in Earth Systems and Environmental Sciences Elsevier.

OPYPA. 2019. Oficina de Programación y Política Agropecuaria. Anuario. Ministerio de Ganadería, Agricultura y Pesca. Diciembre 2019. Montevideo. N 27. https://descargas.mgap.gub.uy/OPYPA/Anuarios/Anuario\%202019/ ORIGINAL \%202019\%20OPYPA\%20INTERACTIVO \%20agregado $\% 20$ 18-12-2019.pdf (last access in 18/05/2020)

OVERBECK, G.E., MÜLLER, S.C., FIDELIS, A., PFADENHAUER, J., PILLAR, V.D., BLANCO, C.C., BOLDRINI, I.I., BOTH, R. \& FORNECK, E.D. 2007. Brazil's neglected biome: The South Brazilian Campos. Perspect. Plant Ecol. Evol. Syst. 9(2):101-116.

OYHANTÇABAL, G. \& NARBONDO, I. 2011. Radiografía del agronegocio sojero: Descripción de los principales actores y los impactos socioeconómicos en Uruguay. REDES-AT, Montevideo.

PARACCHINI, M.L., PACINI, C., JONES, M.L.M. \& PÉREZ-SOBA, M. 2011. An aggregation framework to link indicators associated with multifunctional land use to the stakeholder evaluation of policy options. Ecol. Indic. 11(1):71-80.

PARERA, A., PAULLIER, I. \& BOSSO, A. 2012. Incentivos para conservar los pastizales del cono sur. Una propuesta para gobiernos y productores rurales, Aves Uruguay.

PARUELO, J.M., GUERSCHMAN, J.P. \& VERÓN, S.R. 2005. Expansión agrícola y cambios en el uso del suelo. Cienc. Hoy 15(87):14-23.

PARUELO, J.M., JOBBÁGY, E.G., OESTERHELD, M., GOLLUSCIO, R. \& AGUILAR, M.R. 2007. The grasslands and steppes of Patagonia and the Rio de la Plata plains. Phys. Geogr. South Am. 232-248.

PASCUAL, U. et al. 2017. Valuing nature's contributions to people: the IPBES approach. Curr. Opin. Environ. Sustain. 26:7-16.

PILLAR, V.P., MULLER, S.C., CASTILHOS, Z.M.S. \& JACQUES, A.V.A. 2009. Campos Sulinos: conservação e uso sustentável da biodiversidade. Ministério do Meio Ambiente, Brasília.

PEDRANA, J., BERNAD, L., MACEIRA, N.O. \& ISACCH, J.P. 2015. Conflict between the Greater Rhea and humans in agricultural landscapes: Implications for conservation of the last large herbivore of the southern Pampas. Emu 115(4):335-344.

PEDRANA, J., BERNAD, L., MACEIRA, N.O. \& ISACCH, J.P. 2018. Niche Overlap Determination Through Habitat Suitability Models: A Management Tool for Native Birds of the Argentinean Pampas. Ardeola 65(1):25-40.

PEREIRA MACHÍN, M. \& MORALES, H. 2012. Mesa de Ganadería sobre Campo Natural: una oportunidad para pensar y actuar.

PHIFER, C.C., KNOWLTON, J.L., WEBSTER, C.R., FLASPOHLER, D.J. \& LICATA, J.A. 2017. Bird community responses to afforested eucalyptus plantations in the Argentine pampas. Biodivers. Conserv. 26(13):3073-3101.

PIQUER-RODRÍGUEZ, M., BUTSIC, V., GÄRTNER, P., MACCHI, L., BAUMANN, M., GAVIER PIZARRO, G., VOLANTE, J.N., GASPARRI, I.N. \& KUEMMERLE, T. 2018. Drivers of agricultural land-use change in the Argentine Pampas and Chaco regions. Appl. Geogr. 91:111-122.

RAMESH, T., BOLAN, N. S., KIRKHAM, M. B., WIJESEKARA, H., KANCHIKERIMATH, M., SRINIVASA RAO, C., SANDEEP, S., RINKLEBE, J., SIK OK, Y., CHOUDHURY, B.U., WANG, H., RAYKOFF, J. 2015. Producción animal sostenible en pastoreo sobre campo natural. Unidad de Capacitación, UGP, MGAP, Montevideo.

REDO, D.J., AIDE, T.M., CLARK, M.L. \& ANDRADE-NÚÑEZ, M.J. 2012. Impacts of internal and external policies on land change in Uruguay, 20012009. Environ. Conserv. 39(2):122-131. 
ROSITANO, F., BERT, F.E., PIÑEIRO, G. \& FERRARO, D.O. 2018. Identifying the factors that determine ecosystem services provision in Pampean agroecosystems (Argentina) using a data-mining approach. Environ. Dev. 25:3-11.

SABATINO, M., ROVERE, A. E. \& MACEIRA, N. 2016. Germination of Eryngium regnellii: a major species for ecological restoration of plantpollinator interactions in the Southern Pampas (Buenos Aires, Argentina). Phyton-Int J Exp Bot. 84(2):435-443.

SÁEZ, A., SABATINO, M. \& AIZEN, M. 2014. La diversidad floral del borde afecta la riqueza y abundancia de visitantes florales nativos en cultivos de girasol. Ecol. Austral 24(1):94-102.

SATORRE, E.H. 2005. Cambios tecnológicos en la agricultura argentina actual. Cienc. hoy 15(87):24-31.

SAyDS. 2020. Secretaría de Ambiente y Desarrollo SustenTable de la Nación. Informe del estado del ambiente 2018. https://www.argentina.gob.ar/ noticias/informe-del-estado-del-ambiente (last access in 17/02/2020).

SCHLESINGER, W.H. \& ANDREWS, J.A. 2000. Soil respiration and the global carbon cycle. Biogeochemistry 48(3):7-20.

SCHOOLEY, R.L. \& BRANCH, L.C. 2011. Habitat quality of source patches and connectivity in fragmented landscapes. Biodivers. Conserv. 20(8):1611-1623.

SCHRÖTER, M., KRAMER, R., CEAUŞU, S. \& RUSCH, G.M. 2017. Incorporating threat in hotspots and coldspots of biodiversity and ecosystem services. Ambio 46(7):756-768.

SILVA, J.P., TOLAND, J., JONES, W., ELDRIDGE, J., THORPE, E. \& O'HARA, E. 2008. LIFE and Europe's grasslands: Restoring a forgotten habitat. Office for Official Publications of the European Communities, Luxembourg.

SILVA, J.S. \& RANIERI, V.E.L. 2014. The legal reserve areas compensation mechanism and its economic and environmental implications. Ambient. e Soc. 17(1):115-132.

SISTEMA DE ESTADÍSTICA AMBIENTAL. 2019. Áreas protegidas terrestres y marinas. Available. http://estadisticas.ambiente.gob. ar/?idarticulo=13950\# estadi (last access in 08/10/2019).

SNOECK, M., CASACUBERTA, C., DOMINGO, R., PASTORI, H. \& PITTALUGA, L. 2008. The Emergence of new successful export activities in Uruguay. Research Network Working Paper 548, Inter-American Development Bank.

SORIANO, A., LEÓN, R.J.C., SALA, O.E., LAVADO, S., DEREGIBUS, V.A., CAUHEPÉ, M.A., SCAGLIA, O.A., VELÁZQUEZ, A.. \& LEMCOFF, J. 1991. Río de la Plata Grasslands. In Ecosystems of the World 8A, Natural Grasslands, Introduction and Western Hemisphere. (R. T. Coupland, eds). Elsevier, New York, pp. 367-407.

SOUTO, G. 2012. Oleaginosos y derivados: situación y perspectivas. Anuario OPYPA 2012. Ministerio de Ganadería, Agricultura y Pesca (MGAP), Montevideo.

SOUTULLO, A. \& GUDYNAS, E. 2006. How effective is the MERCOSUR's network of protected areas in representing South America's ecoregions? Oryx 40(1):112-116.

SOUTULLO, A., CLAVIJO C. \& MARTÍNEZ-LANFRANCO J.A. 2013. Especies prioritarias para la conservación en Uruguay. Vertebrados, moluscos continentales y plantas vasculares. SNAP/DINAMA/MVOTMA y DICYT/MEC, Montevideo.
STURZENEGGER, A. 2006. Discriminación al agro en Argentina 1960-2005. Universidad Nacional de La Plata, La Plata.

TRIGO, E. 2005. Consecuencias económicas de la transformación agrícola. Ciencia hoy, 15(87): 46-51.

TSCHARNTKE, T., KLEIN, A.M., KRUESS, A., STEFFAN-DEWENTER, I. \& THIES, C. 2005. Landscape perspectives on agricultural intensification and biodiversity - Ecosystem service management. Ecol. Lett. 8(8):857-874.

VAN MEIJL, H., VAN RHEENEN, T., TABEAU, A. \& EICKHOUT, B. 2006. The impact of different policy environments on agricultural land use in Europe. Agr Ecosyst Environ. 114(1): 21-38.

VEGA, E., BALDI, G., JOBBÁGY, E.G. \& PARUELO, J. 2009. Land use change patterns in the Río de la Plata grasslands: The influence of phytogeographic and political boundaries. Agric. Ecosyst. Environ. 134(3-4):287-292.

VERVOORST, F.B. 1967. Las Comunidades vegetales de la depresión del Salado (Provincia de Buenos Aires). Buenos Aires.

VIGLIZZO, E. \& JOBBÁGY, E.G. 2010. Expansión de la frontera agropecuaria en Argentina y su impacto ecológico-ambiental. Buenos Aires.

VIGLIZZO, E.F. \& FRANK, F.C. 2006. Land-use options for Del Plata Basin in South America: Tradeoffs analysis based on ecosystem service provision. Ecol. Econ. 57(1):140-151.

VIGLIZZO, E.F., LÉRTORA, F., PORDOMINGO, A.J., BERNARDOS, J.N., ROBERTO, Z.E. \& DEL VALLE, H. 2001. Ecological lessons and applications from one century of low external-input farming in the pampas of Argentina. Agric. Ecosyst. Environ. 83(1-2):65-81.

VILLARINO, S.H., STUDDERT, G.A. \& LATERRA, P. 2019. How does soil organic carbon mediate trade-offs between ecosystem services and agricultural production? Ecol. Indic. 103:280-288.

WEYLAND, F., MASTRANGELO, M.E., AUER, A.D., BARRAL, M.P., NAHUELHUAL, L., LARRAZÁBAL, A., PARERA, A.F., BERROUET CADAVID, L.M., LÓPEZ-GÓMEZ, C.P. \& VILLEGAS PALACIO, C. 2019. Ecosystem services approach in Latin America: From theoretical promises to real applications. Ecosyst. Serv. 35:280-293.

WINCK, B.R., SACCOL DE SÁ, E.L., RIGOTTI, V.M. \& CHAUVAT, M. 2017. Relationship between land-use types and functional diversity of epigeic Collembola in Southern Brazil. Appl. Soil Ecol. 10949-59.

ZHANG, W., DULLOO, E., KENNEDY, G., BAILEY, A., SANDHU, H. \& NKONYA, E. 2019a. Biodiversity and Ecosystem Services. In Sustainable Food and Agriculture (C. Campanhola \& S. Pandey, eds). Academic Press, p.137-152.

ZHANG, Y., LONG, H., TU, S., GE, D., MA, L. \& WANG, L. 2019b. Spatial identification of land use functions and their tradeoffs/synergies in China: Implications for sustainable land management. Ecol. Indic. 107: 105550 